\title{
EDUCATIONAL MANAGEMENT FOR ELEMENTARY BASED ON BAIQUNIYYAH KORANIC SCHOOL
}

\author{
Ahmad Agung Yuwono Putro \\ Primary Education, Postgraduate Program \\ State University of Yogyakarta, Indonesia \\ agung@upy.ac.id
}

\author{
Suyanto \\ Primary Education, Postgraduate Program, State \\ University of Yogyakarta, Indonesia
}

\author{
Yoyon Suryono \\ Primary Education, Postgraduate Program \\ State University of Yogyakarta, Indonesia
}

\begin{abstract}
This research aims at analyzing education being held in the elementary school based on the principles of Baiquniyyah Koranic School. The elementary school has a purpose to direct the students' potential development based on the religious understanding. This school has two blended views, the formal and Koranic education. This school was built not recently and it has developed significantly ever since. This paper describes the implementation of Koranic school to the elementary in which it is located on the village of Wonokromo, Pleret, Bantul of Yogyakarta with the method of case studies. It found: (1) the curriculum being implemented is the result of combining the national curriculum, religion minister curriculum and the Koranic curriculum. The final form is the elementary school with the basis of Koranic ones, (2) the educational institution of Baiquniyyah is led by a religious venerated scholar which is considered has a high knowledge. He is helped by teachers, in which they are gained classified. It means there is no publicity in gaining the teachers and the staff, (3) the students are obligated to live in dormitory provided by the school and follow the rules, (4) the funding management is transparent by considering the humanity, in which the institution maintain/establish the low cost so it will be reachable by all people with the possibility of giving dispense for parents/students who are under poverty.
\end{abstract}

Keywords: management, koranic school, baiquniyyah koranic as the basis of elementary school

\section{INTRODUCTION}

Javanese people always demand harmony between the way of thinking and live by respecting each other among people who are bound by the norms of history, tradition and religion. The tradition of Javanese has been implemented in all aspects of live. Their attitude has own identity bounded by the heredity of the ancient until this modern era (Putro, 2017). One of districts in Java that holds history and religion values up to now is Wonokromo, Pleret, Bantul, Yogyakarta that is considered as 'Koranic students' due to increased amount of koranic schools in that area (Departemen Agama RI, 2016). The district/village has a heritance of a Mosque, its name is Taqwa. This mosque was built in the era of Mataram Kingdom in which it has the political function such as a media to strengthen Islamic ideology, citizen's cultures, and the basis og people struggle to defeat the colonialist (Hidayat, 2011).

The religion and cultural values are still strongly held by the society of Javanese in Wonokromo proven by the existence of cultural activities of religion and culture based. One of the realization of culture and religion based is koranic school (Putro, 2017). Based on the data issued by Indonesian Spiritual Ministry (2016), there are 18 koranic schools existed in Wonokromo, Pleret,
Bantul, Yogyakarta consisted on children, adolescence and adult koranic schools. We present the name and location of koranic school existed in Wonokromo village, Pleret, Bantul, Yogyakarta in Table 1 .

Based on that Table 1, 18 units of koranic schools are existed which are consisted of 17 units of adult and adolescence and 1 unit for children koranic school. Based on the interview with the founding father of Baiquniyyah, $\mathrm{KH}$ Imaduddin, it was explained that after being graduated from Koranic school of Lirboyo, East Java, he had a plan to build a school with satisfying religion learning results. In 1984, a Koranic school was built as a place to study and learn which was focused on women students. It was named Baiquniyyah, taken from 'Baiquni" which was originated from the name of the founding father's son, 'Iyyah" means woman.

\section{METHODS}

This is a qualitative research with the approach of case study, aiming to analyze human behavior in particular circumstances, locations and cases. A case study research is a depth study or observation regarding particular events, locations and cases to reveal and understanding something (Creswell, 2009). This research was conducted on an 
elementary school with koranic school based Baiquniyyah located on Jejeran District RT 05 RW 07, Wonokromo, Pleret, Bantul Yogyakarta with the aims to reveal the education system conducted in the school. The subjects of this research are the people participate in the process of teaching and learning such as the founding father, headmaster, caretakers, teachers, students and citizens around the school. Direct and participant observation, in depth interview, documentation and physical artifacts were the data collection technique being used during conducting the research.

\section{RESULT AND DISCUSSION} The Vision of Baiquniyyah Elementary School

The vision of Baiquniyyah Elementary School is to make the students who have balance among spirituality, intellectuality and morality to be become ulul abab generation that committed to Islam and all of its aspects. It includes keeping sustainable environments with the basis of Allah SWT so that the teaching and learning process will be based on Allah SWT. Because of that, the process will be quality, highly competition behavior, spirituality and intellectuality oriented to realize the people of rahmatan lil alamin.

Table 1

Name and Location of Koranic School Existed

in Wonokromo Village, Pleret, Bantul, Yogyakarta

\begin{tabular}{clll}
\hline Number & Name of Koranic School & \multicolumn{1}{c}{ Adress } & \multicolumn{1}{c}{ Level } \\
\hline 1. & Abdul Aziz & Imogiri Km. 7 Wonokromo 1 & Adolescence and adult \\
2. & Al-Fithroh & Jejeran Avenue Wonokromo & Adolescence and adult \\
3. & Al-Futuh & Pandes Wonokromo Pleret & Adolescence and adult \\
4. & Al-Mahalli & Brajan Monokromo Plered & Adolescence and adult \\
5. & Al-Munajah & Wonokromo II & Adolescence and adult \\
6. & An-Ni'mah & Kanggotan RT 09 RW 06 & Adolescence and adult \\
7. & Baiquniyyah & Jejeran & Children \\
8. & Binaul Ummah & Ploso & Adolescence and adult \\
9. & Darul Qur'an Al-Imam & Wonokromo & Adolescence and adult \\
10. & Fadlum Minalloh & Wonokromo 1 & Adolescence and adult \\
11. & Miftahul Ulum II & Jejeran & Adolescence and adult \\
12. & Muhammadiyah & Kanggotan & Adolescence and adult \\
13. & Nahdlatusy Syubban & Kanggotan & Adolescence and adult \\
14. & Nurul Mu'min & Kerto & Adolescence and adult \\
15. & Ridlo & Bawuran & Adolescence and adult \\
16. & Roudlotul Fatihah & Wonokromo 2 & Adolescence and adult \\
17. & Syifaul Qulub & Kanggotan RT 2 RW 5 & Adolescence and adult \\
18. & Wali Songo & Gebang & Adolescence and adult \\
\hline
\end{tabular}

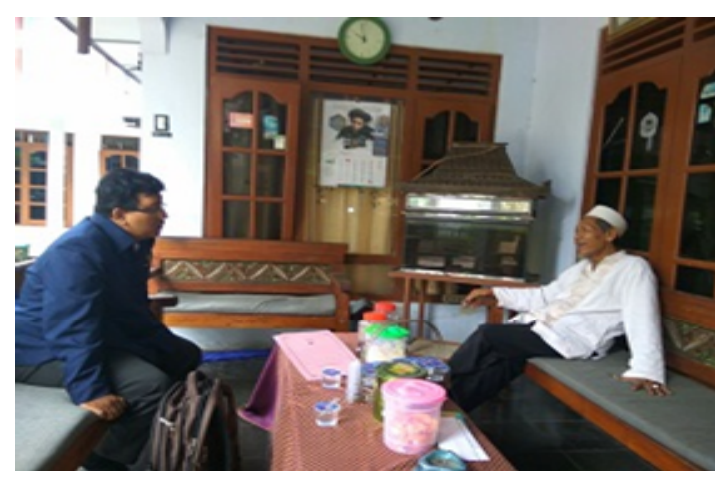

Picture 1 Interviewing the Founding Father of Baiquniyyah Koranic School

(Picture resource: Putro, 2017)

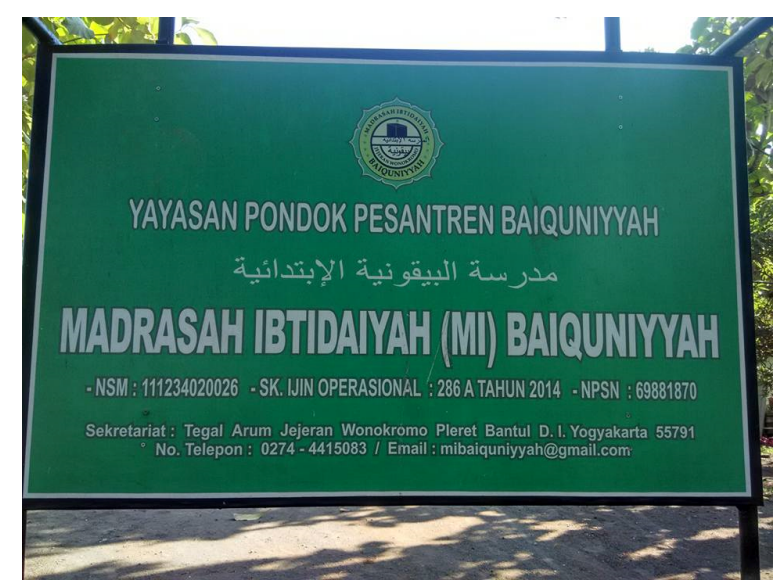

Picture 2 Elementary School with the Dorm of Baiqunniyah (Picture resource: Putro, 2017) 
The vision of this school is based on AlQur'an Surat At-Taubah verse 122 that is "wamaa kaanalmu'minuuna liyanfiruu' kaffatan falawla nafaro min kulli firqatin minhum laifatun liyatafaqqahoo fee alddeeni waliyunthiroo qawmahum itha rajauu ilayhim la allahum yahdzaruun", meaning that "it should not for everyone to go to the battle area. It is better for some of the people to study in depth regarding the religion to warn others, so the others can save themselves" (Putro, 2017).

\section{The Leadership in Elementary Koranic School of Baiquniyyah}

Leadership is an activity of human to guide, direct and organize and it shows relationship and influence between the leader and the people as the consequence of interaction among themselves (Pam Nilan, 2009; Akbar Ali, 2012; Kasful Anwar Us, 2015). The leadership pattern in Baiquniyyah Elementary School is based on venerated scholar as the founding father, owner and governor. It means that working activities, structure of organization, planning, and policy making is verticalize, meaning that the venerated scholar is the single leader that owns the deepest knowledge regarding Islam compared to others.

\section{Curriculum and Learning Organization in Baiquniyyah Elementary School}

Curriculum is the learning design that provided by an institution for the students containing many kinds of competencies that should be achieved by the students (Kieran Egan, 2003; İbrahim Hakk1 Öztürk, 2011; Anna Klebansky \& Sharon P. Fraser, 2013), including Baiquniyyah, this school is fundamentally based on the curriculum that has been designed to achieve the goals. There are three kinds of curriculum being implemented in this school, those are: National Curriculum that is appropriated based on the student's level, Spiritual Department Curriculum, and the curriculum of Koranic School as the characteristic of Islamic school (Putro, 2017).

Curriculum development in this school integrates KTSP, it includes formal learning subjects, spiritual curriculum containing the learning of yellow book, and koranic school curriculum provided by Baiquniyyah that obligates students to live in the dormitories in the school. The implementation of these three curriculums made this school unique. There are some principles in designing curriculum of this school:

1. The achieved competencies in every single subject are developed based on religion values.
2. Knowledge and education that are based on religion values should be free from meaningless and narrow ideas.

3. Curriculum design has sustainability, properness and program blend among the development of intelectuality, skill and character development.

The curriculum being implemented in Baiquniyyah is the combination of formal and koranic ones; it contributes to the development of student's character. It is proven by the students' discipline in undergoing every single scheduled activity, their friendliness to others, and their respect to the elders (Putro, 2017).

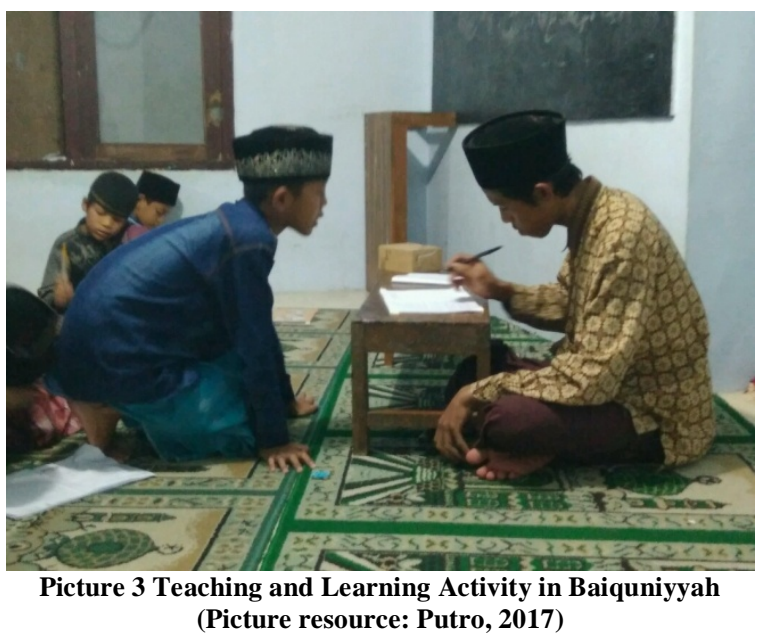

The researcher found that in designing the curriculum, there are some materials being taught out of formal context as the characteristics of koranic school, those are the sorogan, bandongan or wetonan, especially for the subjects specific on koranic school. The focus of this research is on observing the hidden curriculum to increase students' passionate on religion values, so that the teachers are demanded to conduct high quality of education. The indicators, based on Department of Education and Training Melbourne (2015), are:

1. The education is conducted professionally that focused on the students, not teachers need. The aim is that the learning process will be fascinated so the students will grow the potentiality.

2. The education focuses on students' daily activities, not only when they are at school.

3. The quality of education is always upgraded trough research, so that the learning activities will be effective and continuously developed, not only now but also sustainable. 
4. The education process is collaboratively conducted, meaning that all participants solve the problems to increase the quality of output.

5. The education is conducted concretely and contextually based on the data and proves, not only on theories and assumption on behalf on evaluation.

6. The education is conducted sustainability, supported and integrated with the culture and operational system such as schools, network, district and centre of education.

7. The education is everyone's responsibility, not just the individual and group, but also district and central government.

The result of research regarding blended curriculum of formal and religious in Baiquniyyah shows that curriculum is a media that creates conducive and efficient learning environment. The form of curriculum that built as a foundation for teacher staff is in the form of syllabus, learning plan being used as conducting the learning process. Daily, mid and final semester are used to evaluate the learning and judgement process to measure the achievement of learning process. Evaluation is conducted to give information and feedback regarding students performance on behalf of material being taught in class. It is a parameter to decide whether the students should remide, left behind, or enter the next level.

\section{Human Resource Management in Baiquniyyah Elementary School}

Human resource management is a part of organization function that develops the workers. Human resources is a vital part because it is the pillar to run the organization (Bill Mulford, 2003; Stamatios Lourmpas \& Athanasia Dakopoulou, 2013; Ekpenyong E. Ekanem, 2015). Human resources, in this case is teaching staffs that needed by educational elementary school that have competency on knowledge, character, pedagogic to understand students and have social capacity supported by integrity, initiative, and understand religion values.

The closed management is implemented to organize teaching staffs in Baiquniyyah Elementary school in which the teaching staff is recruited underground with no publication at all for particular group of people with the experience of teaching Koranic School. It is because the people with experience of teaching Koranic school will be much easier to adapt to another Koranic ones without any more training. The development of quality of the teaching staffs runs well by conduction sustainable guidance including koranic reading, workshop and seminar.

\section{Means Management of Baiquniyyah Koranic School}

Basically, means education management is a process of using resources including tools, buildings, fields and owned assets (Fred C. Lunenburg, 2010; Hamimah Adnan, et al, 2012; Kris Hemme, 2015). This kind of management is an activity that has been conducted since long time ago so that the learning process is effectively conducted. This management includes buying the means, using, keeping and controlling. Need analysis is a part of planning activity for 1 year. The planning in this elementary school is being prospered based on the need and efficient principles. It includes: (1) buying, designing and ordering such as uniforms, chairs, tables etc, (2) designing, such as mosques, field and etc, (3) buying, such as marker, eraser, writing tools, etc.

Supplying means in Elementary School of Baiquniyyah id conducted systematically by discussing it with all members of Baiquniyyah to decide something. The committee being elected to buy things will analyze the needed and the prices. The committee will be over whenever all the needed are fully prepared. The important thing in this means buying process is that the proper between the fund and the things. If the need requires not much money, it will be quickly available to buy. On the other hand, if it is expensive, the need will be postponed to buy until the fund is available. The next step is to make a list to check the belongings.

The process of checking the belongingness that conducted systematically will give impact on the regularity of using the needs of every member of Koranic school so that the things will be available every time needed. The management after the needs are inventarized is the using and maintenance. In the process of using tools or means should be proper with the function. The lending system is manually recorded in a big book and it becomes the borrower's responsibility. It should obey the school regularity. It is hoped that the means or the tools are properly used based on the functions for every one of the member of the school.

\section{Funding Management of Baiquniyyah Elementary School}

Funding management is very crucial for the existence of educational institution, moreover, it is koranic school with a high complexity. It can be said that a good funding management is very important (J.R Hough, 1993; Muhammad Yunas , 2014; Rose Kahavizakiriza, et al, 2015). The open pattern management has been applied in Baiquniyyah by considering the implementation of management function of RAPBS design, allocation of fund, 
direction for funding every single of activity, and money control.

The system of funding management being implied in Baiquniyyah is so much different from paternalistic management that is considered as closed management. The actors who do the management are the ones who have close relationship with the founding father, however, all of them have passed the test to measure the ability and loyality. The pattern of opened management is very complicated by asserting orientation values to the accountability in funding management in every single activity in this school. The values orientation are the values being implemented by the leaders of this school, those are openedness, Allah bless. It is proven by the existence of students who are not capable to pay the school fee, but still allowed to join the school activities.

The important finding in the implementation of funding management in this elementary school is that this pattern has not developed the surrounding economy, which are farmer and seller. As the consequence, the source of school funding is still limited, the main sources are from individual funding and the school fee from the students. It is continuously paid but actually still can be raised. Besides from the school fee, actually the school still able to develop productive economic activities to raise the school fund. One of them is to manage Koperasi Pondok Pesantren (Kopontren). The existence of Kopontren is hopefully can balance the funding system that is managed professionally based on the government policy.

\section{Students Management in Baiquniyyah Elementary School}

Students management is the management to the students, starting the first day until they are graduated. The concept of students management is a reality that students have strategic roles in teaching and learning process in a school. Students are the subject of the management, with that important management, school should be able to organize students effectively and efficiently (Barry S. Parsonson, 2012; Haydar, 2013; Miqdadi, 2014). The modern management is implemented in Elementary Baiquniyyah by considering management functions from the function of planning of the activity of registering the freshmen. Those include organizing students to enter particular class based on particular categorization, directing the extra curricular as the media of talent development, and controlling students' activities. Those activities are conducted by principle and the teacher of Koranic School.

The conducting of students; management function is that students planning in and educational institution is the process of finding, considering and deciding of someone to become the student of a particular school. The planning activities include: (a) the forming of committee of freshmen registeration. (b) installing the announcement to register the freshmen which is openly conducted. One important thing in planning the students is that the openedness so that the process will be transparent. The openedness management being implemented in Baiquniyyah, especially in students management is rather different from management of another aspects, such as teacher staffs or funding management that are more considered as cloed management. Although it is closed, the research shows that Baiquniyyah never rejects students who are willingly learn in this school. They consider that rejecting students mean rejecting Allah's bless. Students who are not capable to pay the school fee can find another way in other he or she still can study in Baiquniyyah.

In the process of organizing and controlling the students, Baiquniyyah is more considered as modern management that supported by complete students administration. Besides that, leader and teacher staffs support every students activity. One thing that still have not been managed well, that is the alumnae. Some suggestion the researcher gave related to the alumnae are: (a) facilitate the forming of alumnae committee as the communication media, and (b) held acitivities related to the alumnae such as seminar.

\section{Citizens' relation management of Baiquniyyah Elemantary School}

The activity of citizen relationship in academic environment is principally defined as the school activity to create a harmony relationship to support the effective and efficient school education. This understanding is interpreted as a process of communication between school and environment surroundings to raise citizen's understanding that education is important and develop cooperation among them. The relationship with the society is the traditional pattern, in which school dominates the communication among students, parents and school. Besides, the role of the school is still normative such as koranic reading and others related to the religion activities. It seems that parents' roles are still minimum, especially in giving constructive critic. It is unique if we are talking about society's relationship pattern, it is still simple and need a kind of invention to be opened between school and the society. This openedness will impact on the society's understanding that they own the school.

\section{CONCLUSION}

The main purpose of establishing Baiquniyyah, according to the founding father $\mathrm{KH}$. 
Imaduddin, is to establish the education media and produce students who are intellectuality and spirituality high. That idea demands a balance curriculum, between the formal and spiritual ones. The integration of that education way was initiated in elementary school. The formal education in a school is a struggle to form knowledge, behavior and skill, starting from kindegarteen up to the university level. In another way, koranic school develops the spirituality of the students. Those two positive goals blended and create outputs which are highly knowledge, character and spirituality well.

\section{REFERENCES}

[1] Adnan, H., Fauzi, Z. F. M., Rahmat, I., and Supardi, A. Maintenance Management for Public Infrastructure for Malaysian Local Authorities. Journal of Engineering and Applied Sciences, Vol. 7, No. 11, ISSN 1819-6608, 2012.

[2] Ali. Leadership and its Influence in Organizations A Review of Intellections. International Journal of Learning \& Development, ISSN 2164-4063 2012, Vol. 2, No. 6. DOI 10.5296/ijld.v2i6.2690. 2012.

[3] Creswell, J. W. Research Design Qualitative, Quantitative, and Mixed Methods Approaches. SAGE Publications, Inc, 2009.

[4] Department of Education \& Training Melbourne. Professional Learning in Effective Schools The Seven Principles of Highly Effective Professional Learning. McLaren Press, 2005.

[5] Egan, K. What Is Curriculum? Journal of the Canadian Association for Curriculum Studies, Vol. 1 Number 1 Spring, 2003.

[6] Ekanem, E. E. Staff-Personnel Management Towards Technical and Vocational Education: Management Implication for University Graduate Employability in Cross River State. European Journal of Training and Development Studies, Vol. 2, No.1, 2015.

[7] Haydar. The Importance of School Management Has Been Increasing in Student Academic Success, Based on International Exams, Turkey. International Journal on New Trends in Education and Their Implications, 2013.

[8] Hemme, K. Critical Infrastructure Protection: Maintenance is National Security, Texas. Journal of Strategic Security, Vol. 8, No. 5, DOI 10.5038/19440472.8.3S.1471, 2015.

[9] Hidayat, A. R. Masjid sebagai Pelestari Tradisi (Kajian Fungsi Masjid Wonokromo Bantul Yogyakarta dalam Perspektif Historis. Jurnal Analisa, Volume XVIII, No. 02, 2011.

[10] Hough, J. R. Financial Management in Education. Loughborough University, 1993.

[11] Kahavizakiriza, R., Walela, K. B., and Danstanwanyonyikukubo. Financial Management in Public Secondary Schools in Kenya: A Case Study of Lurambi Subcounty Kakamega County, Kenya. International Journal of Scientific \& Technology Research, Vol. 4, Issue 9, 2015.
[12] Klebansky and Fraser, S. P. A. Strategic Approach to Curriculum Design for Information Literacy in Teacher Education-Implementing an Information Literacy Conceptual Framework. Australian Journal of Teacher Education, doi 10.14221/ajte.2013v38n11.5, 2013.

[13] Lourmpas, S., and Dakopoulou, A. Educational Leaders and Teachers' Motivation for Engagement in Innovative Programmes: The Case of Greece. Procedia - Social and Behavioral Sciences, 116, 3359-3364, 2013.

[14] Lunenburg, F. C. School Facilities Management. Journal National Forum of Education Administration \& Supervision, Vol. 27, No. 4, 2010.

[15] Miqdadi, F. Z., Al-Momani, A. F., Mohammad, T., Masharqa, S., and Elmousel, N. M. The Relationship between Time Management and the Academic Performance of Students from the Petroleum Institute in Abu Dhabi. The UAE, USA: ASEE Zone I Conference, 2014.

[16] Mulford. School Leaders: Changing Roles and Impact on Teacher and School Effectiveness. A Paper Commissioned by the Education and Training Policy Division, OECD, for the Activity Attracting, Developing and Retaining Effective Teachers, 2003.

[17] Nilan, P. The Spirit of Education in Indonesian Pesantren. British Journal of Sociology of Education, Vol. 30, No. 2, Routledge, 2009.

[18] Öztürk, I. H. Curriculum Reform and Teacher Autonomy in Turkey: The Case of the History Teaching. International Journal of Instruction, Vol.4, No.2 p-ISSN: 1694-609X, 2011.

[19] Parsonson, S. Evidence-based Classroom Behaviour Management Strategies. Journal of Kairaranga, Vol. 13, Issue 1, 2012.

[20] Putro, A. Y. Religious Humanism of Education in the Baiquniyyah Koranic School. Dissertation, 2017.

[21] Us., K. A. The Leadership of Kyai in Islamic Boarding School (A Study of Islamic Boarding School in Jamb). Department of School Education Administration, the Graduate School, DOI 10.15548/jt.v22i1.113.

[22] Yunas, M. Financial Management for Improving Efficiency of Schools: Issues and Concerns, Pakistan. International Journal of Education and Social Science, Vol. 1 No. 1, 2014. 